\title{
PEMBERDAYAAN TENAGA PENDIDIK MELALUI PELATIHAN ENTREPRENEURSHIP DI SEKOLAH CITRA BERKAT DAN SEKOLAH CITRA KASIH
}

\author{
Daniel Kurniawan $^{1}$, Denny Bernadus ${ }^{1}$, Tina Melinda ${ }^{1^{*}}$ \\ ${ }^{1}$ Program Studi satu, Universitas Ciputra, Surabaya, Indonesia \\ *Email: tina.melinda@ciputra.ac.id
}

\begin{abstract}
Informasi Artikel Abstrak
Kata kunci:

Covid19, Transformasi

digital, Pelatihan

entrepreneurship .

Diterima: 16-06-2021

Disetujui: 05-01-2022

Dipubikasikan: 28-01-

2022

Dalam menghadapi era pandemi Covid-19 yang mengharuskan setiap sekolah melakukan pembelajaran jarak jauh melalui daring, muncul kendala yang menghambat para murid memperoleh pendidikan yang berkualitas dan dampak dari transformasi digital yang hadir begitu pesat sehingga semakin berkembang platform pendidikan digital yang memberikan tawaran yang menarik, pihak sekolah memerlukan adanya keterampilan tambahan yang dapat memperlengkapi setiap tenaga pendidik yang ada di internal sekolah untuk menjawab tantangan yang ada. Entrepreneurship sangat diperlukan bagi tenaga pendidik sebagai keterampilan yang dapat memperlengkapi dalam menghadapi perubahan tersebut. Pelatihan entrepreneurship dilaksanakan oleh program S2 Magister Manajemen Universitas Ciputra bekerja sama dengan Sekolah Citra Berkat dan Sekolah Citra Kasih di Indonesia sebagai program kegiatan pengabdian masyarakat. Pelatihan diberikan oleh dosen, mahasiswa dan para praktisi dari dunia usaha. Para peserta pelatihan merupakan tenaga pendidik yang ada di sekolah tersebut. Pelatihan dilakukan selama 4 bulan berturut sejak Februari hingga Mei 2021 melalui media zoom. Para peserta memperoleh nilai rata-rata 90 dari hasil evaluasi yang diberikan yang berarti para peserta dapat menerapkan pengetahuan yang diperoleh selama pertemuan berlangsung. Kegiatan pelatihan enterpreneur bagi tenaga pendidik dapat terlaksanakan dengan baik dan memberikan dampak bagi setiap sekolah.
\end{abstract}

\section{Keywords:}

Covid19, Digital transformation, Entrepreneurship training

\section{Abstract}

In the face of the Covid-19 pandemic era, which mandates that every school conduct distance learning via online, there are barriers that prevent students from receiving a quality education, as well as the impact of digital transformation, which is occurring at such a rapid pace that digital education platforms are rapidly developing with attractive offers. Additional abilities are needed in schools so that every educator in the internal school can respond to the current issues. Entrepreneurship is an essential talent for educators to have in order to handle these developments. The Masters of Management program at Ciputra University, in cooperation with the Citra Berkat School and the Citra Kasih School in Indonesia, provides entrepreneurship training as a community service activity 
program. Lecturers, students, and practitioners from the business sector provide the training. Participants in the course are school teachers. The training took place over the course of five months, from January to June 2021, and was conducted entirely online. Each meeting was attended with great zeal and excitement by the participants. The knowledge obtained during the meeting can also be put to use by the participants. Following the instruction, the school achieved significant improvements. Any school, especially every instructor who will develop broader capabilities, especially in the sphere of entrepreneurship, requires entrepreneur training.

\section{PENDAHULUAN}

Di era pandemi Covid-19 saat ini, sekolah-sekolah dari jenjang TK hingga Perguruan Tinggi di seluruh dunia menghadapi tantangan yang cukup berat dalam melaksanakan kegiatan belajar mengajar. Berdasarkan data UNESCO per 11 Juni 2021, lebih dari 190 juta anak didik dari 21 negara di dunia harus mengalami penutupan sekolah dan melakukan kegiatan belajar mengajar di luar sekolah (Unesco, 2021). Kondisi ini membawa perubahan besar di dalam dunia pendidikan yang semula dilakukan secara tatap muka di sekolah termasuk di Indonesia yang juga mengalami dampak dari pandemic Covid-19. Pemerintah di Indonesia membuat kebijakan dengan menutup setiap sekolah untuk menghindari penyebaran Covid-19 dan kegiatan belajar mengajar dapat dilaksanakan dengan melakukan pembelajaran jarak jauh (PJJ) di rumah masing-masing (Azzahra, 2020).Pembelajaran jarak jauh dapat dilakukan melalui sistem pembelajaran dalam jaringan (daring) yaitu sistem pembelajaran yang dilaksanakan secara online menggunakan smartphone, laptop atau komputer (Putria et al., 2020). Namun dibalik PJJ secara daring tersebut menghadirkan kendala yang baru bagi setiap pihak yaitu pihak sekolah sebagai fasilitas pendidikan, pihak orang tua yang menjadi pendamping selama PJJ berlangsung dan pihak murid yang beradaptasi dengan sistem belajar dari rumah tersebut (Prasetyo, 2020). Kendala-kendala yang terjadi saat PJJ secara daring tersebut perlu diatasi segera supaya tidak menjadi hambatan bagi setiap murid untuk menerima pembelajaran yang berkualitas. Peran pemerintah dalam mengatasi kendala tersebut cukup beragam antara lain melalui program belajar di TV, bermitra dengan berbagai platform edukasi digital dan pengalokasian dana bantuan operasional sekolah (BOS) untuk menyediakan fasilitas internet gratis bagi para guru dan murid (Abdila, 2020). Kualitas pembelajaran selama PJJ secara daring tersebut juga memerlukan peran sekolah dimana merupakan faktor yang penting selain konektivitas, lingkungan digital yang aman dan bersahabat (Sepülveda, 2020). Hal tersebut menjadikan setiap sekolah khususnya para tenaga pendidik didorong supaya memiliki kreativitas maupun inovasi sehingga kegiatan belajar mengajar dapat menghasilkan pembelajaran yang berkualitas.

Selain itu, kondisi pandemi ini telah menghasilkan percepatan dalam transformasi secara digital bagi seluruh aspek baik di aspek pendidikan maupun aspek bisnis. Jika sebelumnya transformasi digital dianggap sebagai model bisnis di masa depan karena memerlukan biaya yang cukup tinggi dan 
beberapa hal yang kompleks, maka pada kondisi pandemi saat ini setiap organisasi harus mengadopsi transformasi digital supaya dapat bertahan hingga berkembang (Nurcahyadi, 2020). Transformasi digital dalam berbagai aspek juga didorong dengan keberadaan generasi milenial dan generasi $\mathrm{Z}$ yang merupakan proporsi terbesar di dalam masyarakat khususnya di Indonesia sehingga fakta tersebut berimplikasi pada pendekatan pasar terhadap generasi yang telah terbiasa dengan dunia digital tersebut (Sayekti, 2021). Banyak perusahaan berusaha mengimplementasikan strategi yang sesuai bagi generasi digital yang mana memiliki beragam kebutuhan, pandangan dan preferensi. Umumnya generasi milenial dan generasi $\mathrm{Z}$ tersebut menitikberatkan pada kenyamanan, juga pada beberapa faktor seperti kecepatan, kemudahan dan keamanan yang dapat mudah diakses di smartphone mereka masing-masing (Raval, 2019). Transformasi digital dalam dunia pendidikan dapat terlihat dari perkembangan yang cukup banyak pada platform-platform digital yang menyediakan fasilitas pembelajaran dengan fitur dan promosi yang menarik (Adit, 2020). Hal tersebut menjadikan para tenaga pendidik yang terdiri dari kepala sekolah, guru-guru, dan para tenaga administrasi dituntut untuk dapat mengikuti perkembangan yang begitu pesat akibat transformasi digital saat ini sehingga dibutuhkan keterampilan tambahan dalam mengatasi tantangan tersebut.

Untuk membantu pihak sekolah dalam mengatasi tantangan yang ada, Program S2 Magister Manajemen Universitas Ciputra bekerjasama dengan Yayasan Citra Berkat mengadakan pelatihan entrepreneurship bagi pihak sekolah dari jenjang TK hingga SMA sebagai bentuk program kegiatan pengabdian masyarakat. Pelatihan entrepreneurship tersebut dilaksanakan bagi sekolah yang ada di bawah naungan Yayasan Citra Berkat yaitu Sekolah Citra Berkat (SCB) dan Sekolah Citra Kasih (SCK). Pihak sekolah yang berpartisipasi dalam pelatihan entrepreneurship tersebut diwakilkan oleh tenaga pendidik antara lain kepala sekolah, guru-guru dan tenaga administrasi. Pelatihan tersebut bertujuan untuk memperlengkapi keseluruhan internal sekolah dengan keterampilan entrepreneurship secara komprehensif. Entrepreneurship dibutuhkan bagi para tenaga pendidik sebagai bentuk keterampilan yang dapat mendorong proses kreativitas dan inovasi untuk mengembangkan pemecahan masalah dan menemukan peluang yang baru atau berbeda, baik dalam bentuk barang, jasa, ide, maupun metode (Manurung, 2013). Pelatihan entrepreneurship tersebut dapat mendorong para tenaga pendidik untuk mengembangkan kompetensi yang tidak hanya dalam bidang pendidikan yang dasar saja namun jiga pada bidang entrepreneurship dan akan menjadikan sekolah yang semakin profesional (Suryandari et al., 2021). Dengan adanya jiwa entrepreneur, para tenaga pendidik akan menjadi seorang yang kreatif, memiliki keberanian untuk mengambil resiko, percaya diri dan mau bekerja keras untuk menemukan inovasi dalam suatu permasalahan (Arti et al., 2016).

\section{METODE}

Kegiatan pengabdian masyarakat berikut merupakan kerjasama antara Yayasan Citra Berkat dan Program S2 Magister Manajemen Universitas Ciputra yang melibatkan 7 dosen dan 6 mahasiswa 
yang menjadi narasumber dalam pelatihan dengan peserta yang terdiri dari tenaga pendidik di SCK dan SCB yang berada di Indonesia berjumlah 45 orang. Kegiatan tersebut dilaksanakan secara online menggunakan media zoom selama 4 bulan dari bulan Februari 2021 hingga Mei 2021. Tahapan dalam kegiatan pengabdian masyarakat yang dilakukan antara lain sebagai berikut:

- Tahap pendataan para peserta pelatihan yang akan berpartisipasi dan dilakukan oleh pihak sekolah masing-masing yaitu SCK Citra Garden City Jakarta berjumlah 6 orang, SCB Citra Raya Tangerang berjumlah 6 orang, SCB Citra Indah Timur Cibubur berjumlah 6 orang, SCK Citraland City Samarinda berjumlah 5 orang, SCK Citraland Manado berjumlah 4 orang, SCK Citraland Bay View City Ambon berjumlah 3 orang, SCB Citraland Surabaya berjumlah 6 orang, SCB Taman Dayu berjumlah 4 orang, SCK Don Bosco Pondok Indah Jakarta berjumlah 5 orang.

- Kemudian para dosen dan mahasiswa melakukan penjadwalan kegiatan yang diberikan kepada setiap peserta yang telah terdaftar beserta rencana dan topik kegiatan yang akan dilakukan saat pelatihan berlangsung. Para peserta dari setiap sekolah wajib mengikuti rangkaian kegiatan berdasarkan jadwal kegiatan yang telah diperoleh supaya nantinya para peserta dapat menunjukkan perkembangan yang dapat diukur dari setiap penugasan atau tes yang diberikan

- Lalu pelaksanaan kegiatan diawali dengan pemberian materi yang diberikan selama pertemuan secara online melalui media zoom dibawakan oleh para dosen dan mahasiswa S2 Magister Manajemen Universitas Ciputra juga melibatkan para praktisi dunia usaha yang dapat membantu memberikan gambaran situasi pasar secara utuh di masa kini.

- Pada akhir pelaksanaan kegiatan pelatihan tersebut, para peserta dapat menerapkan pengetahuan yang diperoleh melalui workshop dan presentasi yang menjadi penugasan. Tugas tersebut dikerjakan oleh para peserta sesuai dengan situasi masing-masing sekolah dan dilakukan secara berkelompok yang dibagi berdasarkan masing-masing sekolah. Kemudian tugas tersebut akan dievaluasi dan menjadi penilaian dari tugas tersebut dapat digunakan sebagai tolak ukur keberhasilan dari keseluruhan kegiatan yang berlangsung.

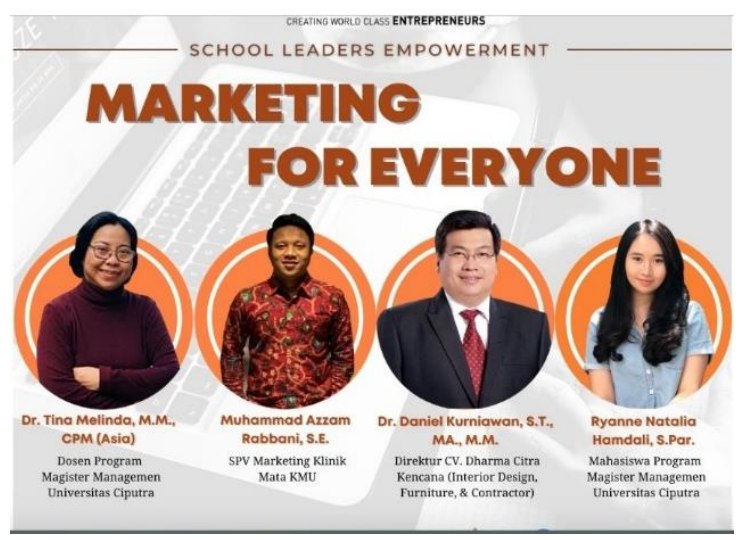

Gambar 1. E-poster dari pertemuan tanggal 3 Februari 2021 


\section{HASIL DAN PEMBAHASAN}

Pada pelaksanaan kegiatan pelatihan entrepreneur tersebut mempertemukan peserta yang merupakan tenaga pendidik dari setiap SCB dan SKB yang tersebar di berbagai daerah secara online Para peserta memperoleh materi secara bersama-sama dan mempraktekkan teknik marketing yang diajarkan sesuai dengan situasi yang dihadapi pada lingkungan sekolah. Materi yang diberikan kepada para peserta di dalam pelatihan enterpreneur tersebut berdasarkan jadwal pelaksanaan kegiatan yang telah ditentukan antara lain

Tabel 1. Materi kegiatan pengabdian masyarakat pelatihan enterpreneur

\begin{tabular}{|c|c|c|}
\hline Tanggal & Tema & Tujuan \\
\hline 03-Feb-21 & $\begin{array}{l}\text { Marketing For } \\
\text { Everyone }\end{array}$ & $\begin{array}{l}\text { Para peserta dapat memahami pentingnya pemasaran dan } \\
\text { aspek-aspek pemasaran }\end{array}$ \\
\hline $10-\mathrm{Feb}-21$ & $\begin{array}{l}\text { Marketing } \\
\text { Breakthrough }\end{array}$ & $\begin{array}{l}\text { Para peserta mengerti cara berinovasi di dalam menyusun } \\
\text { strategi pemasaran di dunia pendidikan }\end{array}$ \\
\hline 24-Feb-21 & $\begin{array}{l}\text { Analisa Situasi } \\
\text { Internal dan Eksternal }\end{array}$ & $\begin{array}{l}\text { Para peserta bisa melakukan analisa secara internal dan } \\
\text { eksternal sebagai alat untuk mencapai tujuan organisasi }\end{array}$ \\
\hline 10-Mar-21 & Digital Marketing & $\begin{array}{l}\text { Para peserta mengenali pemasaran secara digital dan } \\
\text { strategi yang digunakan dalam pemasaran digital }\end{array}$ \\
\hline 24-Mar-21 & $\begin{array}{l}\text { Strategi Pemasaran } \\
\text { Industri Pendidikan }\end{array}$ & $\begin{array}{l}\text { Para peserta mampu mengaplikasikan strategi pemasaran } \\
\text { di dunia pendidikan dengan tepat }\end{array}$ \\
\hline 07-Apr-21 & Tactic and Value & $\begin{array}{l}\text { Para peserta memahami cara mengembangkan strategi } \\
\text { pemasaran menggunakan analisa SWOT dan SPACE }\end{array}$ \\
\hline 21-Apr-21 & $\begin{array}{l}\text { Entrepreneurial } \\
\text { Marketing Canvas }\end{array}$ & $\begin{array}{l}\text { Para peserta dapat menerapkan strategi yang telah disusun } \\
\text { di dalam aspek enterpreneur }\end{array}$ \\
\hline
\end{tabular}

21-Mei-21 Presentasi penugasan

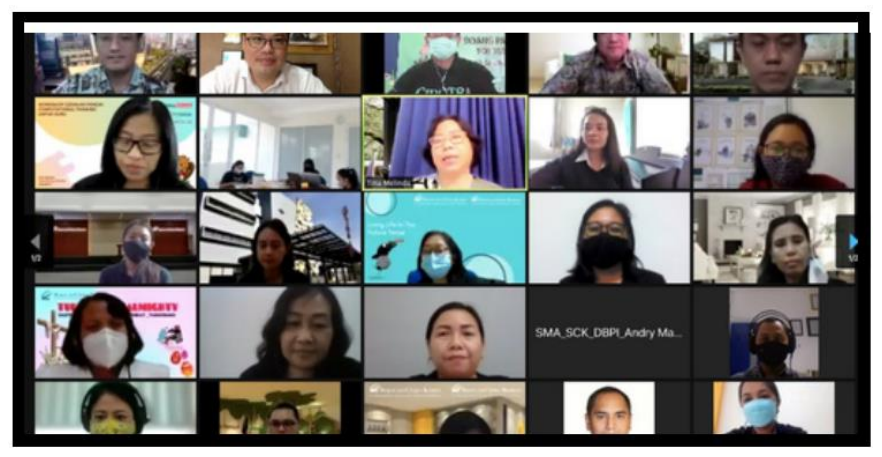

Gambar 2. Dokumentasi pertemuan pada tanggal 21 Mei 2021

Para peserta dapat mengikuti setiap kegiatan dengan baik meskipun kegiatan-kegiatan yang dilaksanakan secara online. Tingkat partisispasi dari peserta dalam masing-masing kegiatan cukup tinggi dapat terlihat dari antusiasme dan semangat para peserta dalam melakukan diskusi maupun memberikan pendapat secara kritis. Pelaksanaan kegiatan pelatihan tersebut juga meningkatkan 
motivasi para peserta untuk mengikuti pelatihan hingga berakhir pada bulan Mei 2021. Hal tersebut ditunjukkan dengan minimnya absen para peserta yang dilakukan pada setiap pertemuan meskipun pelatihan entrepreneur tersebut mengambil waktu di tengah kepadatan jadwal kegiatan belajar mengajar yang masih berlangsung sehingga kegiatan pelatihan tersebut juga dapat memberikan dampak pada perkembangan jiwa enterpreneur yang pesat dalam diri setiap peserta.

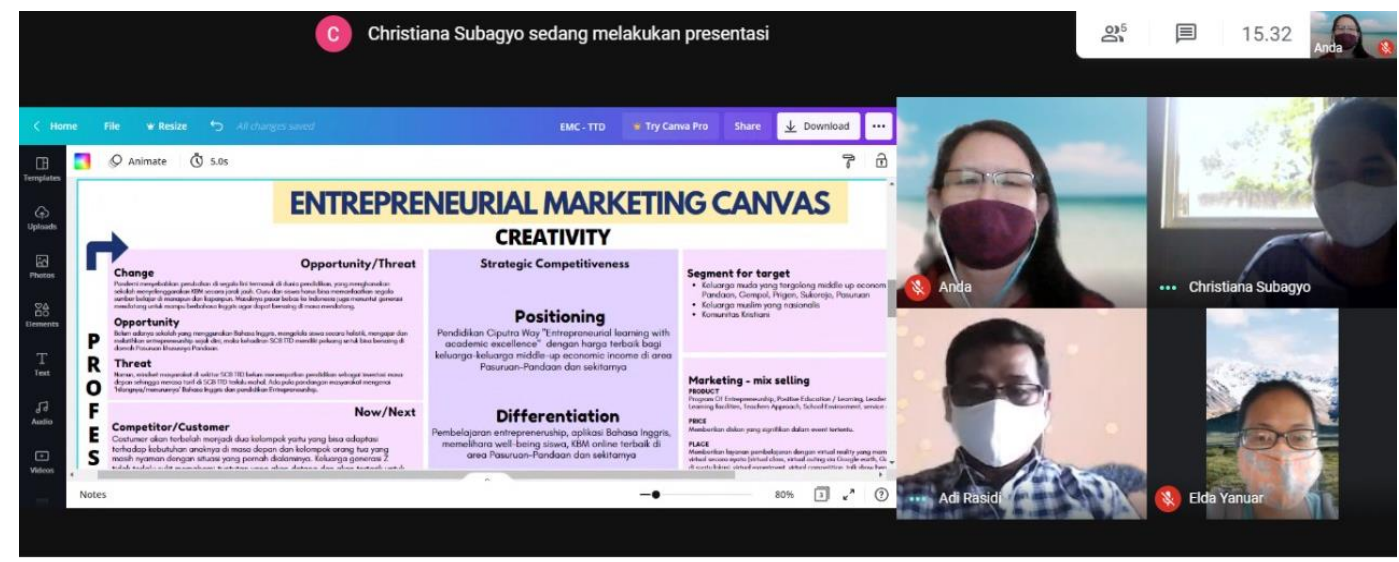

Gambar 3. Presentasi tugas dari SCB Taman Dayu

Pada akhir kegiatan pelatihan, para peserta diwajibkan menerapkan pengetahuan yang diperoleh selama pertemuan berlangsung melalui tugas yang diberikan sebagai evaluasi terhadap pemahaman para peserta. Para peserta mengerjakan tugas tersebut secara berkelompok berdasarkan sekolah masing-masing. Tugas tersebut dinilai berdasarkan butir penilaian yang telah disiapkan yaitu tujuan yang dicapai menggunakan prinsip SMART, strategi pemasaran yang digunakan, memiliki tahapan yang jelas, dan memiliki dampak terhadap sekolah yaitu peningkatan jumlah penerimaan siswa baru. Tugas tersebut dinilai oleh evaluator yang juga memiliki kompetensi di bidang entrepreneur. Hasil evaluasi dari penugasan yang diberikan menunjukkan nilai rata-rata yang diperoleh dari setiap kelompok adalah 90. Hasil tersebut menunjukkan bahwa setiap kelompok dapat menetapkan tujuan yang dicapai menggunakan prinsip SMART, mampu menjelaskan strategi pemasaran yang digunakan, menampilkan tahapan yang jelas dan memiliki dampak pada jumlah penerimaan siswa baru di sekolah yang meningkat. Hasil evaluasi tersebut juga menunjukkan pelatihan tersebut berhasil dipahami dan diterapkan oleh setiap peserta yang telah berpartisipasi sehingga dapat memberikan dampak yang nyata bagi pihak sekolah.

\section{KESIMPULAN}

Kegiatan pengabdian masyarakat berbentuk pelatihan entrepreneur kepada para tenaga pendidik dilaksanakan oleh program S2 Magister Manajemen Universitas Ciputra selama bulan 
Februari hingga Mei 2021. Pelatihan tersebut diikuti oleh tenaga pendidik dari Sekolah Citra Berkat dan Sekolah Citra Kasih untuk mengembangkan keterampilan enterpreneur yang dibutuhkan oleh dunia pendidikan khususnya sekolah yang harus menjawab tantangan dari perkembangan pesat dari transformasi digital yang terjadi di masa kini. Para peserta telah mengikuti setiap rangkaian kegiatan dengan motivasi yang tinggi dan dapat menunjukkan hasil evaluasi yang baik dari penugasan yang diberikan. Pihak sekolah memperoleh dampak dari pelatihan enterpreneur tersebut dengan meningkatnya jumlah penerimaan siswa baru.

\section{UCAPAN TERIMAKASIH}

Penulis mengucapkan terima kasih kepada program S2 Magister Manajemen Universitas Ciputra dan kerjasama dari Yayasan Ciputra yang telah memberikan dukungan sehingga tercapainya program kegiatan pengabdian masyarakat tersebut. Ucapan terima kasih juga diberikan kepada para praktisi usaha yang telah terlibat dalam memberikan materi yang berharga di pelatihan tersebut. Penulis juga mengucapkan terima kasih kepada pihak Sekolah Citra Berkat dan Sekolah Citra Kasih yang telah berpartisipasi dalam pelaksanaan kegiatan pengabdian masyarakat ini hingga akhir.

\section{DAFTAR PUSTAKA}

Abdila, R. (2020). Ragam Upaya Pemerintah Tingkatkan Kualitas Pembelajaran Jarak Jauh. Tribunnews.Com. https://www.tribunnews.com/pendidikan/2020/09/04/ragam-upayapemerintah-tingkatkan-kualitas-pembelajaran-jarak-jauh

Adit, A. (2020). 12 Aplikasi Pembelajaran Daring Kerjasama Kemendikbud, Gratis! Kompas.Com. https://edukasi.kompas.com/read/2020/03/22/123204571/12-aplikasi-pembelajaran-daringkerjasama-kemendikbud-gratis?page $=$ all

Arti, A. N. B., Mudzanatun, \& Agustini, F. (2016). Pengembangan Entrepreneurship Guru Sekolah Dasar Melalui Pembuatan Wayang Pekerjaan. Seminar Nasional PGSD 2016, 1-4.

Azzahra, N. F. (2020). Mengkaji Hambatan Pembelajaran Jarak Jauh di Indonesia di Masa Pandemi Covid-19.

Manurung, H. (2013). Peluang Kewirausahaan Sekolah Melalui Kreativitas dan Inovasi. Journal of Business and Entrepreneurship, 1(1), 1-28.

Nurcahyadi, G. (2020). Pandemi Percepat Transformasi Digital Dalam Bisnis. Mediaindonesia.Com. https://mediaindonesia.com/teknologi/370747/pandemi-percepat-transformasi-digital-dalambisnis

Prasetyo, W. B. (2020). Nadiem Beberkan Hambatan Pembelajaran Jarak Jauh. Beritasatu.Com. https://www.beritasatu.com/nasional/663215/nadiem-beberkan-hambatan-pembelajaran-jarakjauh

Putria, H., Maula, L. H., \& Uswatun, D. A. (2020). Analisis Proses Pembelajaran dalam Jaringan (DARING) Masa Pandemi Covid- 19 Pada Guru Sekolah Dasar. Jurnal Basicedu, 4(4), 861870. https://doi.org/10.31004/basicedu.v4i4.460

Raval, T. (2019). Digital Transformation In The Age Of Millennials And Gen Z. Forbes.Com. https://www.forbes.com/sites/forbestechcouncil/2019/08/20/digital-transformation-in-the-ageof-millennials-and-gen-z/?sh=1f7384c52708

Sayekti, I. M. S. (2021). Potensi Bisnis di Era Milenial Generasi Z. Kontan.Co.Id. 
https://analisis.kontan.co.id/news/potensi-bisnis-di-era-milenial-generasi-z

Sepülveda, A. (2020). The Digital Transformation of Education: Connecting Schools, Empowering Learners.

Suryandari, D., Hidayah, R., Sukirman, Baroroh, N., \& Hajawiyah, A. (2021). Peningkatan Kompetensi Guru Akuntansi Sekolah Menengah Kejuruan Melalui Pengembangan Kewirausahaan. Jurnal Implementasi, 1(1), 65-70.

Unesco. (2021). Education: From disruption to recovery. Unesco.Org. https://en.unesco.org/covid19/educationresponse 